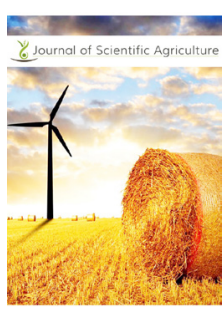

ISSN: $2184^{-0} 0261$

\title{
Nitrogen mineralization and microbial activity as influenced by sulfur sources in an alkaline calcareous soil
}

\author{
Tufail Shah', Zahir Shah², Syed Atizaz Ali Shah³, Nazir Ahmad4* \\ ${ }^{1}$ College of Resources and Environmental Sciences, China Agricultural University-Beijing, P. R. China, ${ }^{2}$ Department \\ of Soil and Environmental Sciences, The University of Agriculture, Peshawar-KPK-Pakistan, ${ }^{3}$ Institute of Agriculture \\ Resources and Regional Planning, The Graduate School of Chinese Academy of Agricultural Sciences-Beijing, \\ P.R. China, ${ }^{4}$ Oil Crops Research Institute (Wuhan), The Graduate School of Chinese Academy of Agricultural \\ Sciences-Beijing, P.R. China
}

\begin{abstract}
A study was performed to check the effects of various sources of sulfur on microbial activity, microbial population, $\mathrm{N}$ mineralization and organic matter content in an alkaline calcareous soil by using soil samples collected from Malakandher Farm at 0-20 cm depth, and analyzed for microbial activity, total mineral nitrogen, bacterial and fungal population and organic matter content. The results showed that the rate of $\mathrm{CO}_{2}$ evolution and cumulative $\mathrm{CO}_{2}$ production were higher in soils amended with elemental sulfur followed by sulfuric acid and gypsum treated soils. The microbial activity decreased with incubation period in all treatments, and the microbial population was greatly affected by sulfur sources. Generally, the bacterial population decreased in soils amended with elemental sulfur, but the population was higher in soils amended with gypsum. Bacterial population was suppressed in soils treated with sulfuric acid. However, the fungal population was higher in soils amended with sulfuric acids was less in soil amended with elemental sulfur. The sulfur amendments promoted immobilization of $\mathrm{N}$. The net $\mathrm{N}$ immobilized was higher in soil amended with gypsum followed by soils amended with sulfuric acid and elemental sulfur. The percent organic matter was higher in soils amended with gypsum and was decreased compared with that amended with elemental sulfur or sulfuric acid. These results suggested that soil microbiological properties changed with sulfur amendments during laboratory incubation.
\end{abstract}

*Corresponding Author:

Nazir Ahmad

Email: nazir_aup@yahoo.com

\section{INTRODUCTION}

Sulfur is a key nutrient for crop production. However, sulfur deficient soils (>100 million ha) are found in many agricultural areas around the globe. Sulfur plays a crucial role in the formation of chlorophyll and a building block of protein. Without adequate $\mathrm{S}$, crops cannot reach their full potential in terms of yield or protein content [1]. Organic matter is the main sources of total sulfur for the soils in the humid area, while gypsum is the main source for the soils in the drier parts. When $\mathrm{S}$ is scarce in the soil, full yield potential of the crop cannot be realized regardless of other nutrients even under good crop husbandry practices. The aftereffects of particulate sulfur supply in soil is of major problem as it creates pollution in agricultural soils.

As there are no minerals containing $\mathrm{N}$ in soil, reserves of $\mathrm{N}$ depend on the soil organic matter content. Thus, $\mathrm{N}$ cycling in soil is closely related to organic matter turnover. Micro-organisms are responsible for soil-N transformations, which play a key role in determining the availability of $\mathrm{N}$ for plant growth and crop production. Therefore, the knowledge of the quality of soil organic matter and understanding of these $\mathrm{N}$-cycling processes are of utmost importance with respect to agricultural systems for the balanced and proper management of external sources of $\mathrm{N}$ in the forms of mineral and organic fertilizers and biologically fixed $\mathrm{N}$. Changes in the $\mathrm{N}$ cycle associated with excessive soil-N loading can have detrimental effects on terrestrial and aquatic ecosystems, such as eutrophication, algal blooms and dead zones.

Soil micro biota, is involved in the macronutrient cycles [2,3], is negatively affected by the fire. Soil microorganisms are susceptible to the indirect environmental changes caused by heat [4]. Microorganisms are responsible in the formation, stabilization, and degradation of soil aggregates $[5,6]$. The present study was carried out to study the effects of different sources of sulfur on $\mathrm{N}$ mineralization and immobilization, microbial population, organic matter content and microbial activity in alkaline calcareous soil.

Copyright: $\odot$ The authors. This article is open access and licensed under the terms of the Creative Commons Attribution License (http://creativecommons.org/licenses/by/4.0/) which permits unrestricted, use, distribution and reproduction in any medium, or format for any purpose, even commercially provided the work is properly cited. Attribution - You must give appropriate credit, provide a link to the license, and indicate if changes were made. 


\section{MATERIALS AND METHODS}

\section{Soil Sampling and Processing}

Soil samples selected at $0-20 \mathrm{~cm}$ depth were collected randomly from 6-8 different spots from Malakandher Farm. Samples of all spots from the same depth were mixed thoroughly to form a composite sample of about $21 \mathrm{~kg}$. Soil samples were transported in cool boxes to the laboratory of the Department of Soil \& Environmental Sciences, The University of AgriculturePeshawar. Soil samples were broken down by hands and sieved through $<2 \mathrm{~mm}$ sieve in fresh and moist form. Samples were run for necessary analysis immediately after sieving or kept at $4^{\circ} \mathrm{C}$ until ready to run.

\section{Soil Amendments with Sulfur Sources}

About $21 \mathrm{~kg}$ of soil was amended with different sulfur amendments. The following treatments were arranged to assess the effect of low $\left(3 \mathrm{tha}^{-1}\right)$ and high $\left(6 \mathrm{tha}^{-1}\right)$ level of sulfur from 3 sources of $\mathrm{S}$ :

\begin{tabular}{lll}
\hline S. No. & Treatments & Rate of application \\
\hline T1 & Control & No sulfur added \\
T2 & S elemental-Low level & $3 \mathrm{t} \mathrm{S} \mathrm{ha}$ \\
T3 & S elemental-High level & $6 \mathrm{t} \mathrm{S} \mathrm{ha}^{-1}$ \\
T4 & H2S04-Low Level & $3 \mathrm{t} \mathrm{S} \mathrm{ha}^{-1}$ \\
T5 & H2S04-High level & $6 \mathrm{t} \mathrm{S} \mathrm{ha}^{-1}$ \\
T6 & Gypsum- Low Level & $3 \mathrm{t} \mathrm{S} \mathrm{ha}^{-1}$ \\
T7 & Gypsum-High level & $6 \mathrm{t} \mathrm{S} \mathrm{ha}^{-1}$ \\
\hline
\end{tabular}

The soil was amended with the desired level and source of $\mathrm{S}$ as per plan and thoroughly mixed into the soil. The samples were incubated at $28^{\circ} \mathrm{C}$. Microbial population (bacteria and fungi), microbial activity, mineralizable $\mathrm{N}$ and Soil organic matter (SOM) were measured during the experiment.

\section{Laboratory Analysis}

\section{Measurement of bacterial and fungal population}

Bacterial and fungal populations were determined by the dilution plate technique as described in [7].

\section{Measurements of $\mathrm{CO}_{2}$ evolution}

Microbial activity was measured by using alkali trapping method. The samples for microbial activity were taken in duplicates from each treatment.

\section{Soil organic matter $(\%)$}

Soil organic matter in soil samples was determined by the Walkley-black procedure using $\mathrm{K}_{2} \mathrm{Cr}_{2} \mathrm{O}_{7}$ as described by [8] .

\section{Total Mineral Nitrogen}

The steam distillation procedure was used for the determination of mineral $\mathrm{N}\left(\mathrm{NH}_{4}-\mathrm{N}\right.$ and $\left.\mathrm{NO}_{3}-\mathrm{N}\right)$. The amount of mineralizable
$\mathrm{N}$ was calculated by difference as follows:

Mineralizable $\mathrm{N}=$ mineral $\mathrm{N}$ at day $10-$ mineral $\mathrm{N}$ at day 0

\section{RESULTS AND DISCUSSION}

\section{The Rate of $\mathrm{CO}_{2}$ Evolution}

Results obtained on the rate of $\mathrm{CO}_{2}$ evolution as influenced by sulfur sources during ten days of incubation periods are given (Table 1, Figure 1). It was observed that the rate of $\mathrm{CO}_{2}$ evolution was generally higher in soil amended with a low and high level of elemental sulfur $\left(\mathrm{T}_{3}\right.$ and $\left.\mathrm{T}_{2}\right)$ during two days of incubation periods. The lowest $\mathrm{CO}_{2}$ during two days of incubation was obtained in soil amended with a low and high level of gypsum. On day 5, the higher rate of $\mathrm{CO}_{2}$ evolution was observed in the treatments amended with elemental $\mathrm{S}$. The same trend was observed at day 10. However, the rate of $\mathrm{CO}_{2}$ evolution decreased in all treatments with time. These results suggested that elemental S significantly promoted microbial activity in soil. It is interesting to note that gypsum amendment somehow depressed microbial activity in soil.

The microbial activity was declined in all treatments, but the significant decline was observed in soils amended with gypsum. However, the reduction in microbial activity in soils

Table 1: Effect of different sources of sulfur on the rate of $\mathrm{CO}_{2}$ evolution $\left(\mu \mathrm{g} \mathrm{CO}_{2} \mathrm{~g}^{-1}\right.$ soil $\left.\mathrm{d}^{-1}\right)$ during ten days of incubation

\begin{tabular}{lccc}
\hline Treatment & $\begin{array}{c}2 \text { days } \\
\text { (Incubation) }\end{array}$ & $\begin{array}{c}5 \text { days } \\
\text { (Incubation) }\end{array}$ & $\begin{array}{c}10 \text { Days } \\
\text { (incubation) }\end{array}$ \\
\hline $\mathrm{T}_{1}$ (Control) & 105 & 26 & 19 \\
$\mathrm{~T}_{2}$ (S Elemental-low level)* & 141 & 39 & 43 \\
$\mathrm{~T}_{3}$ (S Elemental-high level)** & 139 & 47 & 51 \\
$\mathrm{~T}_{4}\left(\mathrm{H}_{2} \mathrm{SO}_{4}\right.$-low level*** & 119 & 24 & 24 \\
$\mathrm{~T}_{5}\left(\mathrm{H}_{2} \mathrm{SO}_{4}\right.$-high level)**** & 173 & 23 & 30 \\
$\mathrm{~T}_{6}$ (Gypsum-low level)***** & 86 & 17 & 23 \\
$\mathrm{~T}_{7}$ (Gypsum-high level)****** & 81 & 21 & 25 \\
Mean & 120 & 28 & 31
\end{tabular}

*Elemental $\mathrm{S}$ at 3 t S ha ${ }^{-1}, * *$ Elemental $\mathrm{S}$ at $6 \mathrm{t} \mathrm{ha}^{-1}, * * * \mathrm{H}_{2} \mathrm{SO}_{4}$ at 3 t S ha- ${ }^{-1} * * * * \mathrm{H}_{2} \mathrm{SO}_{4}$ at 6 t S per ha- ${ }^{-1} * * * * *$ Gypsum at $3 \mathrm{t} \mathrm{ha}^{-1}$, $* * * * *$ Gypsum at 6 t $\mathrm{S}$ ha

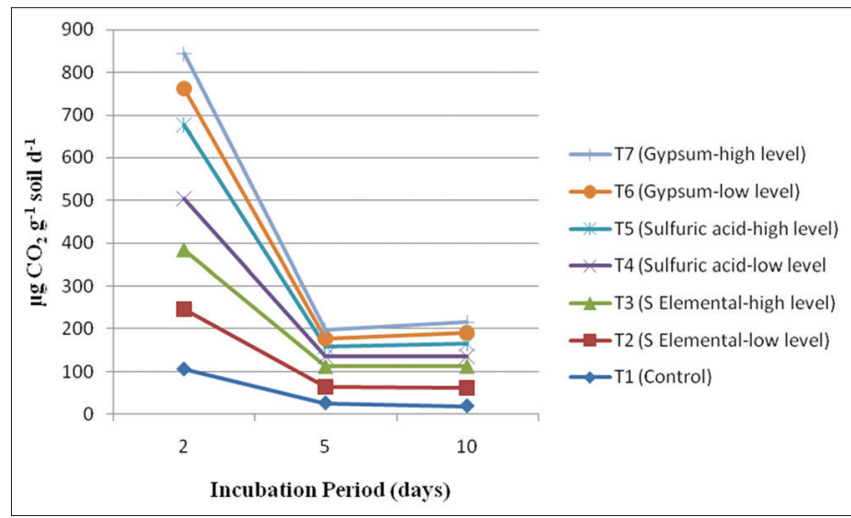

Figure 1: Effect of different sources of sulfur on the rate of $\mathrm{CO}_{2}$ evolution during ten days of incubation period 
amended with elemental sulfur was lesser as compared with that amended with sulfuric acid or gypsum. Application of elemental Sulfur fertilizer caused a significant decrease in microbial activity also reported by [9]. Due to soil acidification, a decline in heterotrophic microbial activity has been studied by [10] [11-13]. Correspondingly, reduced microbial activity was also reported $[14,15]$.

\section{Cumulative $\mathrm{CO}_{2}$ Production}

The results obtained on cumulative $\mathrm{CO}_{2}$ production as influenced by the different sources containing sulfur and incubation periods during ten days of incubation are given (Table 2, Figure 2). It was noticed that the cumulative $\mathrm{CO}_{2}$ production was generally higher in treatments amended with elemental sulfur and was decreased compared with that amended with sulfuric acid, control, and gypsum. According to results, the higher cumulative $\mathrm{CO}_{2}$ production was observed in Sulfur elemental-higher level $277 \mu \mathrm{g} \mathrm{CO} \mathrm{g}^{-1}$ soil d $\mathrm{d}^{-1}$ on day 2, $417 \mu \mathrm{g}$ on day 5 and $670 \mu \mathrm{g} \mathrm{CO} \mathrm{Cg}^{-1}$ soil d $\mathrm{d}^{-1}$ on day ten respectively. In sulfur elemental lower level $283 \mu \mathrm{g}$ on day 2, $400 \mu \mathrm{g}$ on day 5 and $616 \mu \mathrm{g} \mathrm{CO}_{2} \mathrm{~g}^{-1}$ soil d $\mathrm{d}^{-1}$ on day 10 . The lowest $\mathrm{CO}_{2}$ cumulative production was observed in soil amended with gypsum higher and lower levels $162 \mu \mathrm{g}$ on day 2, $223 \mu \mathrm{g}$ on day 5 and $349 \mathrm{CO}_{2} \mathrm{~g}^{-1}$ soil d $\mathrm{d}^{-1}$ on day 10 . In the lower level, $173 \mu \mathrm{g}$ on day 2, $222 \mu \mathrm{g}$ on day 5 and $337 \mu \mathrm{g}$ $\mathrm{CO}_{2} \mathrm{~g}^{-1}$ soil d $\mathrm{d}^{-1}$ on day 10 .

Table 2: Effect of different sources of sulfur on cumulative $\mathrm{CO}_{2}$ production $\left(\mu \mathrm{g} \mathrm{CO}_{2} \mathrm{~g}^{-1}\right.$ soil d $\left.\mathrm{d}^{-1}\right)$ during 10 days of incubation

\begin{tabular}{|c|c|c|c|c|}
\hline Treatment & $\begin{array}{c}2 \text { days } \\
\text { (Incubation) }\end{array}$ & $\begin{array}{c}5 \text { days } \\
\text { (Incubation) }\end{array}$ & $\begin{array}{c}10 \text { days } \\
\text { (incubation) }\end{array}$ & Mean \\
\hline $\mathrm{T}_{1}$ (Control) & 209 & 286 & 383 & 239 \\
\hline $\mathrm{T}_{2}$ (S Elemental-low level)* & 283 & 400 & 616 & 433 \\
\hline $\begin{array}{l}\mathrm{T}_{3} \text { (S Elemental-high } \\
\text { level)** }\end{array}$ & 277 & 417 & 670 & 455 \\
\hline $\mathrm{T}_{4}\left(\mathrm{H}_{2} \mathrm{SO}_{4}\right.$-low level $) * * *$ & 238 & 310 & 428 & 325 \\
\hline $\mathrm{T}_{5}\left(\mathrm{H}_{2} \mathrm{SO}_{4}\right.$-high level $) * * * *$ & 245 & 415 & 567 & 442 \\
\hline $\begin{array}{l}\mathrm{T}_{6} \text { (Gypsum-low } \\
\text { level)*****}\end{array}$ & 173 & 222 & 337 & 244 \\
\hline 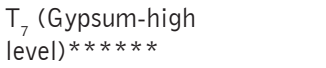 & 162 & 223 & 349 & 245 \\
\hline Mean & 241 & 325 & 487 & 348 \\
\hline
\end{tabular}

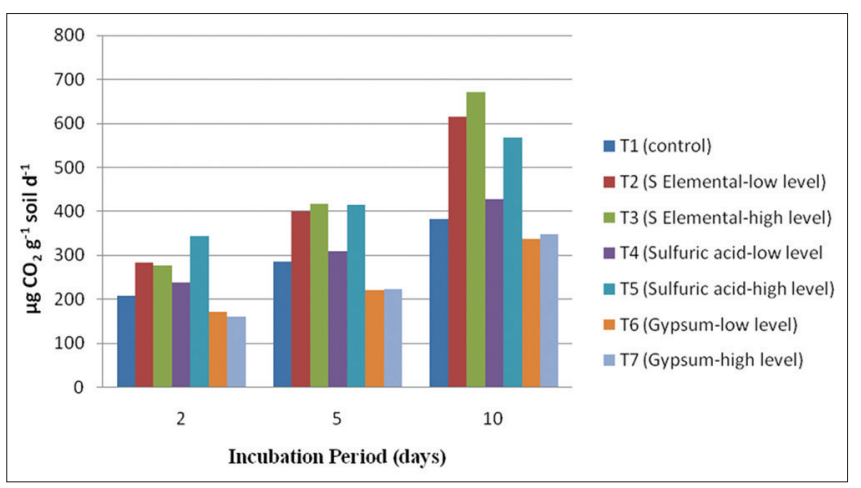

Figure 2: Effect of different sources of sulfur on cumulative $\mathrm{CO}_{2}$ production during 10 days of incubation period

\section{Microbial Population}

The results obtained on the microbial population, i.e. as influenced by different sources containing sulfur and incubation periods during ten days of incubation are given (Table 3). It was observed that bacterial population in control treatment was $9 \times 10^{7} \mathrm{~g}^{-1}, 2.4 \times 10^{8} \mathrm{~g}^{-1}, 1.1 \times 10^{9} \mathrm{~g}^{-1}$ and $1.9 \times 10^{9} \mathrm{cfu} \mathrm{g}^{-1}$ soil on days $0,2,5$ and ten respectively. In sulfur elemental higher level, the bacterial colonies observed were $30.0 \times 10^{7} \mathrm{~g}^{-1}$, $4.1 \times 10^{8} \mathrm{~g}^{-1}, 1.6 \times 10^{9} \mathrm{~g}^{-1}$, and $1.4 \times 10^{9} \mathrm{cfu}^{-1}$ soil on days 0,2 , 5 and ten respectively. The bacterial colonies in a sulfuric acid higher level, the bacterial colonies observed were $4.5 \times 10^{7} \mathrm{~g}^{-1}$, $2.7 \times 108 \mathrm{~g}^{-1}, 0.92 \times 10^{9} \mathrm{~g}^{-1}$ and $2.3 \times 10^{9} \mathrm{cfu} \mathrm{g}^{-1}$ soil on days $0,2,5$ and ten respectively. In gypsum higher level, the bacterial colonies observed were $2.3 \times 10^{7} \mathrm{~g}^{-1}, 7.8 \times 10^{8} \mathrm{~g}^{-1}, 1.5 \times 10^{9} \mathrm{~g}^{-1}$, and $1.5 \times 10^{9} \mathrm{cfu} \mathrm{g}^{-1}$ soil on days $0,2,5$ and ten respectively.

The fungal population was observed much higher in soil treated with sulfuric acid. The colonies observed in control were $2.5 \times$ $10^{7} \mathrm{~g}^{-1}, 6.0 \times 10^{6} \mathrm{~g}^{-1}, 1.3 \times 10^{6} \mathrm{~g}^{-1}$ and $0.80 \times 10^{6} \mathrm{cfu} \mathrm{g}^{-1}$ soil on days $0,2,5$ and 10 respectively. The fungal colonies observed in soil treated with sulfur elemental higher level were $1.6 \times 10^{7} \mathrm{~g}^{-1}$, $0.70 \times 10^{6} \mathrm{~g}^{-1}, 3.5 \times 10^{6} \mathrm{~g}^{-1}$ and $0.25 \times 10^{6} \mathrm{cfu} \mathrm{g}^{-1}$ soil on days $0,2,5$ and ten respectively. The fungal colonies observed in soil treated with sulfuric acid were $11.0 \times 107 \mathrm{~g}^{-1}, 7.5 \times 10^{6} \mathrm{~g}^{-1}$, $5.8 \times 10^{6} \mathrm{~g}^{-1}$ and $1.2 \times 10^{6} \mathrm{cfu} \mathrm{g}^{-1}$ soil on days $0,2,5$ and ten respectively. The fungal colonies in soil treated with gypsum higher level were $3.7 \times 10^{7} \mathrm{~g}^{-1}, 4.0 \times 10^{6} \mathrm{~g}^{-1}, 4.5 \times 10^{6} \mathrm{~g}^{-1}$ and $1.1 \times 10^{6}$ cfu g $^{-1}$ soil on days $0,2,5$ and 10 respectively.

It was observed that fungal population in soil treated with sulfuric acid was much higher compared with the soil amended with sulfur elemental and gypsum. In this case, a much decrease in bacterial population was observed in soil treated with sulfuric acid, because sulfuric acid made the soil favorable for fungi.

There was a reduction in fungal and bacterial populations under sulfur treatments [9]. Generally, the bacterial population was higher in soil treated with gypsum. The population of total bacteria, Azotobacter, Nitrosomonas and Nitrobacter considerably increased due to the application of gypsum also studied [16]. Bacterial activities were also affected by gypsumamended soils as observed [17]. The bacterial populations observed in soil amended with elemental sulfur were much lesser over other treatments. The population of bacteria and fungi were much decreased with the incubation time periods, the population was higher on day 0 followed by 2,5 and 10 .

\section{Total Mineral Nitrogen}

The outcomes obtained on total mineral nitrogen as influenced by different sulfur-containing sources and incubation periods during 10 days of incubation are given (Table 4). Generally, on day 0 , the higher total mineral nitrogen was observed in soil treated with gypsum followed by elemental sulfur, sulfuric acid, and control. The total mineral nitrogen in the gypsum higher level was $67.38 \mu \mathrm{g} \mathrm{N} \mathrm{g}^{-1}$ soil and $3.50 \mu \mathrm{g} \mathrm{N} \mathrm{g}^{-1}$ soil on days 0 and 10. The pure mineral $\mathrm{N}$ mineralized was $-63.88 \mu \mathrm{g}$ 
Table 3: Effect of different sources of sulfur on microbial populations (cfu $\mathrm{g}^{-1}$ soil) in soil during 10 days of incubation period

\begin{tabular}{|c|c|c|c|c|c|c|c|c|}
\hline \multirow[t]{3}{*}{ Treatments } & \multicolumn{8}{|c|}{ The incubation period (days) } \\
\hline & \multicolumn{2}{|c|}{0} & \multicolumn{2}{|c|}{$2^{\text {nd }}$} & \multicolumn{2}{|c|}{$5^{\text {th }}$} & \multicolumn{2}{|c|}{$10^{\text {th }}$} \\
\hline & Bacteria & Fungi & Bacteria & Fungi & Bacteria & Fungi & Bacteria & Fungi \\
\hline$T_{1}$ (Control) & $9 \times 10^{7}$ & $2.5 \times 10^{7}$ & $2.4 \times 10^{8}$ & $6.0 \times 10^{6}$ & $1.1 \times 10^{9}$ & $1.3 \times 10^{6}$ & $1.9 \times 10^{9}$ & $0.80 \times 10^{6}$ \\
\hline $\mathrm{T}_{3}^{1}$ (Sulfur elemental-high level)* & $30.0 \times 10^{7}$ & $1.6 \times 10^{7}$ & $4.1 \times 10^{8}$ & $0.70 \times 10^{6}$ & $1.6 \times 10^{9}$ & $3.5 \times 10^{6}$ & $1.4 \times 10^{9}$ & $0.25 \times 10^{6}$ \\
\hline $\mathrm{T}_{5}^{3}\left(\mathrm{H}_{2} \mathrm{SO}_{4}\right.$-high level $) * *$ & $4.5 \times 10^{7}$ & $11.0 \times 10^{7}$ & $2.7 \times 10^{8}$ & $7.5 \times 10^{6}$ & $0.92 \times 10^{9}$ & $5.8 \times 10^{6}$ & $2.3 \times 10^{9}$ & $1.2 \times 10^{6}$ \\
\hline $\mathrm{T}_{7}^{5}$ (Gypsum-high level)*** & $2.3 \times 10^{7}$ & $3.7 \times 10^{7}$ & $7.8 \times 10^{8}$ & $4.0 \times 10^{6}$ & $1.5 \times 10^{9}$ & $4.5 \times 10^{6}$ & $1.5 \times 10^{9}$ & $1.1 \times 10^{6}$ \\
\hline
\end{tabular}

$\mathrm{N} \mathrm{g}^{-1}$ soil. The total mineral nitrogen in gypsum lower level was $66.50 \mu \mathrm{g} \mathrm{N} \mathrm{g}^{-1}$ soil and $7.00 \mu \mathrm{g} \mathrm{N} \mathrm{g}^{-1}$ soil on days 0 and 10, the net $\mathrm{N}$ mineralized was $-59.50 \mu \mathrm{g} \mathrm{N} \mathrm{g}$ soil. The total $\mathrm{N}$ mineral observed in elemental sulfur higher level was $58.63 \mu \mathrm{g} \mathrm{N} \mathrm{g}$ soil and $10.50 \mu \mathrm{g} \mathrm{N} \mathrm{g}$ soil on day 0 and 10 respectively, the net $\mathrm{N}$ mineralized was $-48.13 \mu \mathrm{g} \mathrm{N} \mathrm{g}^{-1}$ soil. The total mineral $\mathrm{N}$ in the elemental sulfur lower level was $57.75 \mu \mathrm{g} \mathrm{N} \mathrm{g}^{-1}$ soil and $12.25 \mu \mathrm{g}$ $\mathrm{N} \mathrm{g}^{-1}$ soil on days 0 and 10 respectively, the net $\mathrm{N}$ mineralized was $-45.50 \mu \mathrm{g} \mathrm{N} \mathrm{g}^{-1}$ soil. The total mineral nitrogen in sulfuric acid higher level was $58.63 \mu \mathrm{g} \mathrm{N} \mathrm{g}^{-1}$ soil and $5.25 \mu \mathrm{g} \mathrm{N} \mathrm{g}^{-1}$ soil on days 0 and 10 respectively, the net $\mathrm{N}$ mineralized was $-53.38 \mu \mathrm{g}$ $\mathrm{N} \mathrm{g}^{-1}$ soil. The total mineral nitrogen observed in the sulfuric acid lower level was $56.0 \mu \mathrm{g} \mathrm{N} \mathrm{g}^{-1}$ soil and $9.63 \mu \mathrm{g} \mathrm{N} \mathrm{g}^{-1}$ soil on days 0 and 10 respectively, the net $\mathrm{N}$ mineralized was $-46.38 \mu \mathrm{g} \mathrm{N} \mathrm{g} \mathrm{g}^{-1}$ soil. The total mineral nitrogen in control observed was $36.75 \mu \mathrm{g}$ $\mathrm{N} \mathrm{g}^{-1}$ soil and $4.38 \mu \mathrm{g} \mathrm{N} \mathrm{g}^{-1}$ soil on days 0 and 10 respectively; the net $\mathrm{N}$ mineralized was $-32.38 \mu \mathrm{g} \mathrm{N} \mathrm{g}^{-1}$ soil. After incubation, the sulfur amendments promoted Immobilization of $\mathrm{N}$.

\section{Soil Organic Matter (\%)}

The results obtained on soil organic matter as influenced by the different sources containing sulfur and incubation periods during 40 days of incubation are given in Table 5 . It was observed that soil organic matter was higher in soil amended with gypsum followed by control, elemental sulfur (higher and lower level) and sulfuric acid (higher level and lower level). According to results, the percent soil organic matter in soil amended with gypsum of the higher level was $1.12 \%, 1.64 \%, 2.24 \%, 2.73 \%$ and $2.07 \%$ on days $0,5,10,20,40$ respectively. In gypsum lower level $0.98 \%, 2.14 \%, 3.11 \%, 1.54 \%, 2.05 \%$ on days $0,5,10,20$ and 40 respectively. In control, $1.26 \%, 2.16 \%, 1.02 \%, 2.23 \%, 2.42 \%$ on days $0,5,10,20$ and 40 respectively. In elemental sulfur higher level $1.40 \%, 2.50 \%, 0.93 \%, 1.52 \%$ and $2.35 \%$ on days $0,5,10$, 20 and 40 . In elemental sulfur lower level 1.55\%, $2.33 \%, 1.00 \%$, $1.60 \%$ and $2.17 \%$ on days $0,5,10,20$ and 40 . In sulfuric acid higher level the result was $1.41 \%, 1.79 \%, 1.02 \%, 1.79 \%$ and $2.09 \%$ on days $0,5,10,20$ and 40 . The lowest organic matter content was observed in sulfuric acid lower level $0.86 \%, 2.02 \%$, $0.79 \%, 2.09 \%$ and $2.16 \%$ on days $0,5,10,20$ and 40 . [16] The acidification leads to changes in the solubility of organic matter as and such changes might influence the leaching of organic matter [18]. Organic matter contents were built up with the application gypsum [19].

\section{CONCLUSIONS}

Microbial activity in the soil was greatly influenced by sources of sulfur. Elemental S significantly promoted microbial activity
Table 4: Effect of different sources of sulfur on Total mineral $\mathrm{N}\left(\mu \mathrm{g} \mathrm{N} \mathrm{g}{ }^{-1}\right.$ soil) during 10 days of incubation

\begin{tabular}{|c|c|c|c|}
\hline \multirow[t]{3}{*}{ Treatments } & \multicolumn{3}{|c|}{ The incubation period (days) } \\
\hline & 0 & 10 & \multirow[t]{2}{*}{ Net $\mathrm{N}$ mineralizec } \\
\hline & \multicolumn{2}{|c|}{$\mu \mathrm{g} \mathrm{N} \mathrm{g}^{-1}$ soil } & \\
\hline $\mathrm{T}_{1}$ (Control) & 36.75 & 4.38 & -32.38 \\
\hline $\mathrm{T}_{2}$ (S Elemental-low level)* & 57.75 & 12.25 & -45.50 \\
\hline $\mathrm{T}_{3}$ (S Elemental-high level)** & 58.63 & 10.50 & -48.13 \\
\hline $\mathrm{T}_{4}\left(\mathrm{H}_{2} \mathrm{SO}_{4} \text {-low level }\right)^{* * *}$ & 56.00 & 9.63 & -46.38 \\
\hline $\mathrm{T}_{5}\left(\mathrm{H}_{2} \mathrm{SO}_{4}\right.$-high level $) * * * *$ & 58.63 & 5.25 & -53.38 \\
\hline $\mathrm{T}_{6}$ (Gypsum-low level)***** & 66.50 & 7.00 & -59.50 \\
\hline $\mathrm{T}_{7}$ (Gypsum-high level) $* * * * * *$ & 67.38 & 3.50 & -63.88 \\
\hline Mean & 57.38 & 7.50 & -49.88 \\
\hline
\end{tabular}

Table 5: Effect of different sources of sulfur on SOM (\%) during 40 days of incubation

\begin{tabular}{|c|c|c|c|c|c|c|}
\hline \multirow[t]{3}{*}{ Treatment } & \multicolumn{6}{|c|}{ The incubation period (days) } \\
\hline & \multirow[t]{2}{*}{0} & \multirow[t]{2}{*}{5} & 10 & \multirow[t]{2}{*}{20} & \multirow[t]{2}{*}{40} & \multirow[t]{2}{*}{ Mean } \\
\hline & & & S O M (\%) & & & \\
\hline $\mathrm{T}_{1}$ (Control) & 1.26 & 2.16 & 1.02 & 2.23 & 2.42 & 1.81 \\
\hline $\mathrm{T}_{2}^{1}$ (S Elemental-low level)* & 1.55 & 2.33 & 1.00 & 1.60 & 2.17 & 1.73 \\
\hline $\mathrm{T}_{3}(\mathrm{~S}$ Elemental-high level)** & 1.40 & 2.50 & 0.93 & 1.52 & 2.35 & 1.74 \\
\hline $\mathrm{T}_{4}^{3}\left(\mathrm{H}_{2} \mathrm{SO}_{4}\right.$-low level $) * * *$ & 0.86 & 2.02 & 0.79 & 2.09 & 2.16 & 1.58 \\
\hline $\mathrm{T}_{5}^{4}\left(\mathrm{H}_{2} \mathrm{SO}_{4}\right.$-high level $) * * * *$ & 1.41 & 1.79 & 1.02 & 1.79 & 2.09 & 1.62 \\
\hline $\mathrm{T}_{6}$ (Gypsum-low level)***** & 0.98 & 2.14 & 3.11 & 1.54 & 2.05 & 1.96 \\
\hline $\mathrm{T}_{7}$ (Gypsum-high level)****** & 1.12 & 1.64 & 2.24 & 2.73 & 2.07 & 1.96 \\
\hline Mean & 1.23 & 2.08 & 1.44 & 1.93 & 2.19 & 1.77 \\
\hline
\end{tabular}

in soil. Gypsum amendment depressed microbial activity in soil. The rate of $\mathrm{CO}_{2}$ evolution and cumulative $\mathrm{CO}_{2}$ production was decreased in all treatments during the laboratory incubation period. Microbial activity was more significant where the microbial population was high. Bacterial population was depressed by sulfuric acid and elemental sulfur. However, it was greater in soil amended with gypsum. The fungal population was highest in soil amended with sulfuric acid. Before incubation, the total mineral was promoted by sulfur sources. The sulfur amendments promoted immobilization of $\mathrm{N}$ after incubation.

\section{REFERENCES}

1. Zhao FJ, Salmon SE, Withers PJ, Monaghan JM, Evans EJ, Shewry PR McGrath SP. Variation in the bread making quality and rheological properties of wheat in relation to sulphur nutrition under field conditions. Journal of Cereal Science. 1999; 30(1):19-31.

2. Hernández T, Garcia C, Reinhardt I. Short-term effect of wildfire on the chemical, biochemical and microbiological properties of Mediterranean pine forest soils. Biology and fertility of soils. 1997; 25(2): 109-116.

3. Acea MJ, Carballas T. The influence of cattle slurry on soil microbial 
Shah, et al.

population and nitrogen cycle microorganisms. Biological Wastes. 1988; 23(3):229-241.

4. Pietikäinen J, Fritze $\mathrm{H}$. Clear-cutting and prescribed burning in coniferous forest: comparison of effects on soil fungal and total microbial biomass, respiration activity and nitrification. Soil Biology and Biochemistry. 1995; 27(1):101-109.

5. Aspiras RB, Allen ON, Harris RF, Chesters G. The role of microorganisms in the stabilization of soil aggregates. Soil Biology and Biochemistry. 1971; 3 (4):347-353.

6. Vázquez FJ, Acea MJ, Carballas T. Soil microbial populations after wildfire. FEMS Microbiology Ecology. 1993; 13(2):93-103.

7. Wollum II, AG. Cultural methods for soil microorganisms. In: Page, Miller RH, Keeney DR. (Eds.), Methods of Soil Analysis. Agronomy No. 9. (2 ${ }^{\text {nd }}$ Ed.) ASA. SSA. Madison, WI. USA. 1982; 781-801.

8. Nelson DW, Sommers LE. Total carbon, organic carbon, and organic matter. Methods of soil analysis part 3, chemical methods. 1996: 961-1010

9. Gupta VV, Lawrence JR, Germida JJ. Impact of elemental sulfur fertilization on agricultural soils. I. Effects on microbial biomass and enzyme activities. Canadian Journal of Soil Science. 1988; 68(3):463-473.

10. Bewley RJ, Stotzky G. Effects of combinations of simulated acid rain and cadmium or zinc on microbial activity in soil. Environmental research. 1983: 31(2):332-339.

11. Bitton G, Boylan RA. Effect of Acid Precipitation on Soil Microbial Activity: I. Soil Core Studies 1. Journal of environmental quality. 1985; 14(1):66-69.

12. McColl JG, Firestone MK. Cumulative Effects of Simulated Acid
Rain on Soil Chemical and Microbial Characteristics and Conifer Seedling Growth 1. Soil Science Society of America Journal. 1987; 51(3):794-800.

13. Killham K, Firestone MK, Mc Coll JG. Acid Rain and Soil Microbial Activity: Effects and Their Mechanisms 1. Journal of Environmental Quality. 1983; 12(1):133-137.

14. Bewley RJ, Parkinson D. Effects of sulphur dioxide pollution on forest soil microorganisms. Canadian journal of microbiology. 1984; 30(2):179-185.

15. Maynard DG, Germida JJ, Addison PA. The effect of elemental sulfur on certain chemical and biological properties of surface organic horizons of a forest soil. Canadian Journal of Forest Research. 1986; 16(5):1050-1054.

16. Bajpai PD, Gupta BR, Singh C. Some Microbiological Studies in SaltAffected Soils-II. Effect of Gypsum and Mulch on Selected Soil Microflora and Evolution of Carbon dioxide. Journal of the Indian Society of Soil Science. 1976; 24(1):48-52.

17. Anderson DL, Tuovinen $\mathrm{OH}$, Faber A, Ostrokowski I. Use of soil amendments to reduce soluble phosphorus in dairy soils. Ecological Engineering. 1995; 5(2-3):229-46.

18. Stroo HF, Alexander M. Role of Soil Organic Matter in the Effect of Acid Rain on Nitrogen Mineralization 1. Soil Science Society of America Journal. 1986; 50(5):1219-23.

19. Sarwar G, Ibrahim M, Tahir MA, Iftikhar Y, Haider MS, Noor-UsSabah NU, Han KH, Ha SK, Zhang YS. Effect of compost and gypsum application on the chemical properties and fertility status of saline-sodic soil. Korean Journal of Soil Science and Fertilizer. 2011 44(3):510-516 